\title{
Characterization of lake water-groundwater exchange at Lake L5, Universiti Teknologi PETRONAS, Malaysia
}

\author{
K. U. Orji, N. Sapari \& K. W. Yusof \\ Department of Civil Engineering, \\ Universiti Teknologi PETRONAS, Malaysia
}

\begin{abstract}
Mining lakes are rarely used in Malaysia for raw water supply in water treatment despite their abundance. This is based on the general view that they are just mere retention ponds. However, there is growing acknowledgement that surface water features such as rivers and lakes can exchange water with underlying aquifers and this water movement can have significant implications on water quantity. This study examined the interaction between surface water (mining lake water) and groundwater (aquifer) using Lake L5 at the Universiti Teknologi PETRONAS, Perak, Malaysia, as a case study. Seepage meters and mini piezometers were used to evaluate the seepage flux rates, direction, and magnitude of water flow between the aquifer and the lake water. The seepage flux rates were found to be in the range of $3.45 \mathrm{Lm}^{-2} \mathrm{day}^{-1}$ to $11.08 \mathrm{Lm}^{-2} \mathrm{day}^{-1}$ and the Vertical Hydraulic Gradients (VHG) of the mini piezometers was within the range of 0.022 to 0.196 . The results from these methods were positive, correlated and confirmed that groundwater was being discharge into the lake water; and that the farther the monitoring equipment from the shoreline, the lesser the groundwater discharge. Further research is required to be carried out for a longer period, under different hydrological conditions and time of the year, and at several locations.
\end{abstract}

Keywords: mining lake, groundwater, interaction, seepage meters, mini piezometers. 


\section{Introduction}

Rivers provide main water source for $97 \%$ of drinking water supply for domestic, industrial and agriculture in Malaysia [1]. Mining lakes are rarely used for raw water supply for water treatment despite their abundance in the country $[2,3]$. This is based on the general view about mining lakes water in Malaysia. Mining lakes are viewed as retention ponds which can be dried up when used for water supply. However, there is growing acknowledgement that surface water features such as rivers and lakes can exchange water with underlying aquifers and this water movement can have significant implications on water quantity and quality [4]. The degree and nature of connectivity between lakes and groundwater resources influence the extraction, potential, contamination, and flow characteristics. The interaction between surface water (lakes) and groundwater is important because it forms the basic framework in the evaluation of water budgets for water supply and also groundwater transports of chemical solutes to the surface water bodies.

These exchange between groundwater and lakes can occur in three different dimensions vis-à-vis: some lakes recharge groundwater throughout the entire lake beds; others are being recharged by the groundwater throughout the beds; while some lakes receive groundwater inflows in some part of their beds and recharge groundwater through the other parts $[5,6]$.

There are different methods of evaluating fluxes between a lake and aquifer. They include seepage flux (using seepage meter), heat tracer methods, mini piezometer, monitoring wells, pumping tests, hydraulic conductivity, isotopes and chemical tracers, etc. This study used seepage meters and mini piezometers for its evaluations. The reason behind this choice was that these instruments are inexpensive and have direct measurement of seepage flux at the interface between lake and aquifer. The performance of a seepage meter and mini piezometer has been tested in several studies [4, 5, 7-12]. This study sought to evaluate in details the interaction between groundwater and UTP Lake L5 $\left(4^{\circ} 23^{\prime} 08.46^{\prime \prime} \mathrm{N}\right.$ and $\left.100^{\circ} 58^{\prime} 45.36^{\prime \prime} \mathrm{E}\right)$. Its specific objectives were to (i) determine the locations, rates and directions of groundwater seepage using the above methods; and (ii) to compare the results of these methods.

\section{Materials and methods}

\subsection{Description of lake L5}

There are eight lakes located inside the University Teknologi PETRONAS (UTP) campus in Seri Iskandar, Perak, Malaysia. They are labeled as L1, L2, L3, L4, L5, L6, L7, and L8 (Figure 1). L2, L3, L4, and L8 are the upstream lakes of Lake L7, which in turns flows into Lake L6. L5 has a surface area of $68,739.52 \mathrm{~m}^{2}$ (6.874 ha). It is located near the security gate of the university. The lake is part of the UTP chain of lakes which flows into Lake L6. The overall water that flows into Lake L6 is finally discharged to other lakes outside the campus through a weir. 


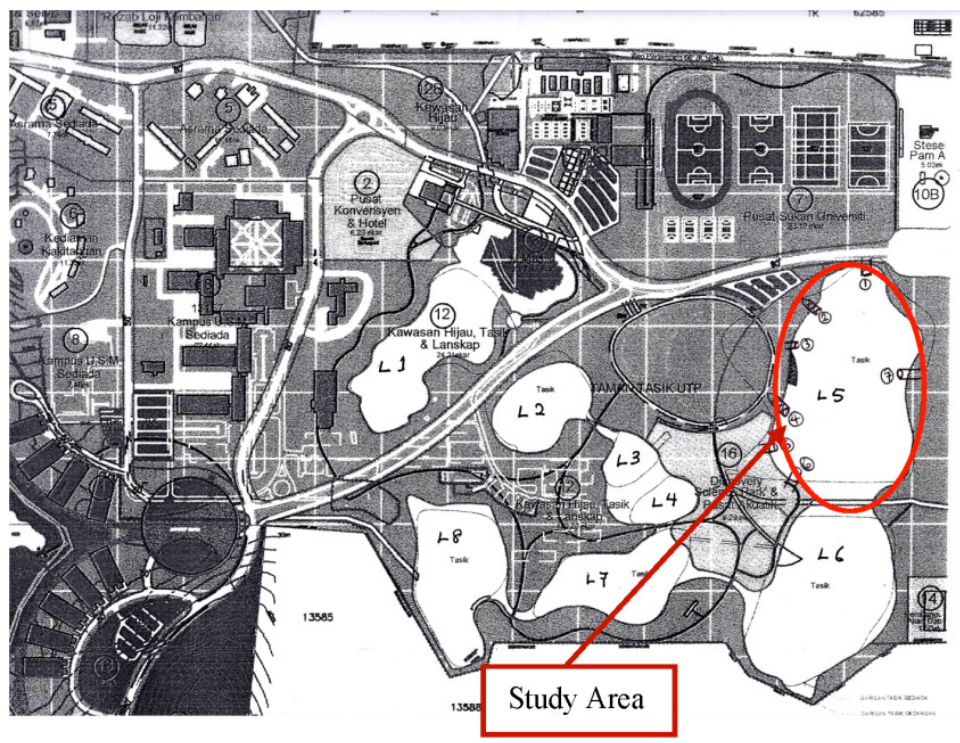

Figure 1: $\quad$ Map of the Universiti Teknologi PETRONAS, UTP $\left(4^{\circ} 23^{\prime} 08.46^{\prime \prime} \mathrm{N}\right.$ and $100^{\circ} 58^{\prime} 45.36^{\prime \prime} \mathrm{E}$ ) showing various mining lakes (source: Maintenance Dept., UTP).

\subsection{Methods}

Two experiments were conducted within the study area. They include measuring the groundwater discharge using seepage meters and mini piezometers.

\subsubsection{Seepage meter}

The quantity of groundwater seepage into the lake was determined using seepage meters. They were designed, constructed and installed at four different locations $\left(\mathrm{T}_{1}\right.$ to $\mathrm{T}_{4}$ ) on the lake bed (Figure 2(a) and (c)). Seepage flux of the lake's groundwater was then measured by enclosing a particular area of the lake bottom with a cylinder vented to a plastic bag [4, 9, 10 and 13]. The meter was constructed using a $200 \mathrm{~L}$ steel drum (diameter $=0.57 \mathrm{~m}$ ) that was cut into halves. Four flanges were welded at the top of the closed end of the drum and each flange was tied to a $6 \mathrm{~kg}$ of rock. This was done to ensure that during installation, the drum moved down to the bottom of the lake without interference. The drum's bung hole ( $1 / 2$ inch) in the closed end was then fitted with a watertight connector that was connected to a $10 \mathrm{~L}$ polyethylene bag through a 2 meter hose (diameter $=15 \mathrm{~mm}$ ) and was tightened using hose clamps and rubber bands. Prior to the installation of the seepage meter, $1 \mathrm{~L}$ of water was introduced into the polyethylene bag and tied to the hose. This was recorded as the initial volume of water in the bag. The seepage meter equalized with the groundwater for twenty four hours before data collection. The collected water in the bag over the twenty four hours represented the amount of groundwater 
seepage which could enter or exit the lake through the lake's bottom. The seepage flux was calculated as follows:

$$
Q=\frac{V_{f}-V_{o}}{t A}
$$

$\mathrm{Q}=$ Seepage flux or seepage volume per area $\left(\mathrm{lm}^{-2} \mathrm{day}^{-1}\right)$

$\mathrm{V}_{\mathrm{f}}=$ Final volume of water in the bag (l)

$\mathrm{V}_{\mathrm{o}}=$ Initial volume of water in the bag (l)

$\mathrm{t}=$ Time elapsed between when the bag was connected and disconnected (day)

$A=$ Surface area of the chamber $\left(0.255 \mathrm{~m}^{2}\right)$.

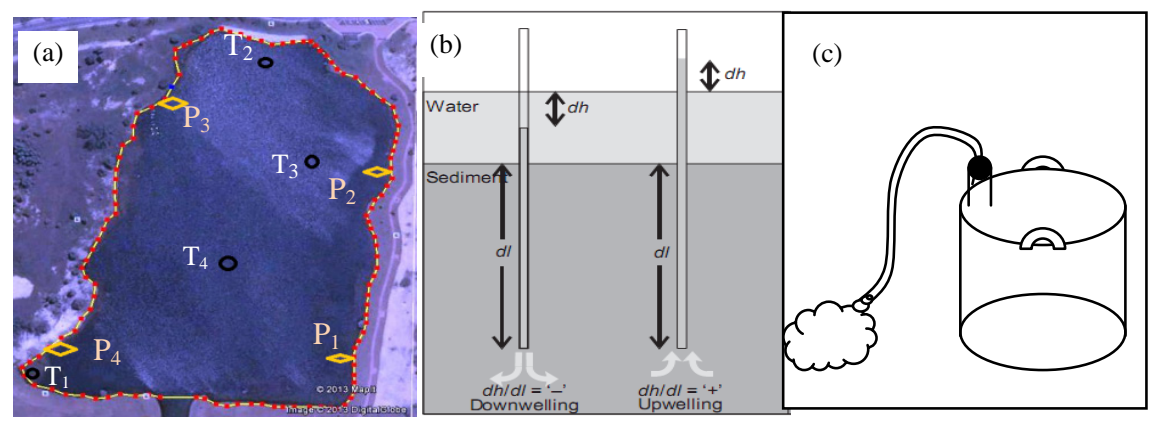

Figure 2: (a) UTP lake 15 showing mini piezometer and seepage meter stations (b) vertical hydraulic gradient in a down welling and upwelling region of the lakebed (adapted from Rautio and KorkkaNiem [5]) and (c) seepage meter.

The values of seepage flux were multiplied by a correction factor of 1.05, which was introduced by Belanger and Montgomery [14], to take care of all the possible errors due to flow resistance to the drum and the plastic bag during the measurements.

\subsubsection{Mini piezometers}

A mini piezometer is a device used to measure the direction of water flow between surface water body such as a lake and aquifer (Figure 2(b)). It estimates the characterization of the magnitude and direction of vertical hydraulic gradient (VHG) $[15,16]$. The Vertical Hydraulic Gradient (VHG) values at certain depths in a single point between a lake and groundwater were computed using the formula:

$$
V H G=\frac{d h}{d l} V H G=\frac{d h}{d l}
$$

$d h=$ hydraulic head difference between the mini piezometer and lake stage $(\mathrm{cm})$; 
$d l=$ vertical distance between the lake bed and the midpoint of the perforated screen mini piezometer $(\mathrm{cm})[5,17]$.

Four piezometer stations $\left(\mathrm{P}_{1}\right.$ to $\left.\mathrm{P}_{4}\right)$ were installed at different locations of the lake (Figure 2(a)). The PVC piezometer has an outer diameter of $2 \mathrm{~cm}$. There were 12 mini piezometers used for the study and had perforated screens of various lengths. They were installed by a hand auger, and drilling of $10 \mathrm{~cm}$ wide borehole. The auger material was used to backfill the borehole after installation. The lake water levels $\left(h_{2}\right)$ were measured with a meter rule, midpoints of the perforated areas marked, and groundwater levels obtained using the water level meter (YAMAYO Million Rope Water Level Measure - $50 \mathrm{~m}$ ). A positive value of VHG indicates groundwater recharges the lake while a negative value shows the opposite. Three mini piezometers were installed perpendicular to the shoreline at each station so as to measure the head differences and to characterize the magnitude and directions of the VHG.

\section{Results and discussions}

\subsection{Seepage meter}

The various volumes of water obtained using seepage meters in these four locations are shown in Table 1.

Table 1: $\quad$ Summary of seepage meter data obtained at UTP lake L5, UTP.

\begin{tabular}{|c|c|c|c|c|c|c|c|c|}
\hline Location & $\begin{array}{c}\text { Lake’s } \\
\text { Depth } \\
(\mathrm{m})\end{array}$ & Date & $n$ & $\begin{array}{c}I \\
(\mathrm{~m})\end{array}$ & $\begin{array}{c}\text { Initial } \\
\text { Volume } \\
(\mathrm{L})\end{array}$ & $\begin{array}{c}\text { Final } \\
\text { Volume } \\
(\mathrm{L})\end{array}$ & $\begin{array}{c}\text { Change } \\
\text { in } \\
\text { Volume } \\
(\mathrm{L})\end{array}$ & $\begin{array}{c}\text { Seepage } \\
\text { Flux } \\
\left(\mathrm{Lm}^{-2}\right. \\
\left.\text { day }^{-1}\right)\end{array}$ \\
\hline T1 & 2.6 & $12 / 11 / 13$ & 1.05 & 3.80 & 1.0 & 3.69 & 2.69 & 11.08 \\
\hline T2 & 5.47 & $13 / 11 / 13$ & 1.05 & 10.54 & 1.0 & 2.20 & 1.20 & 4.94 \\
\hline T3 & 7.8 & $14 / 11 / 13$ & 1.05 & 30.06 & 1.0 & 2.10 & 1.10 & 4.53 \\
\hline T4 & 10.03 & $15 / 11 / 13$ & 1.05 & 98.12 & 1.0 & 1.84 & 0.84 & 3.45 \\
\hline
\end{tabular}

$I$ = distance from shoreline $(\mathrm{m}), \mathrm{n}=$ correction factor.

The seepage flux rates ranged from $3.45 \mathrm{Lm}^{-2} \mathrm{day}^{-1}$ to $11.08 \mathrm{Lm}^{-2} \mathrm{day}^{-1}$. The highest seepage flux was obtained near the shoreline. The study revealed that the seepage fluxes decreased with increasing distance from the shoreline. It also indicated that all the four locations experienced recharge of groundwater into the lake (Figure 3(a)). Rautio and Korkka-Niem [5] and McCann et al . [17] obtained similar results.

\subsection{Mini piezometer}

The measured hydraulic head differences $(d h)$ within the four stations showed upward flow of groundwater (Table 2 and Figure 3(b)-(e)). The study revealed that all the results obtained for the vertical hydraulic gradients (VHG) were positive. It was also deduced from the study that the greater the installation depth 


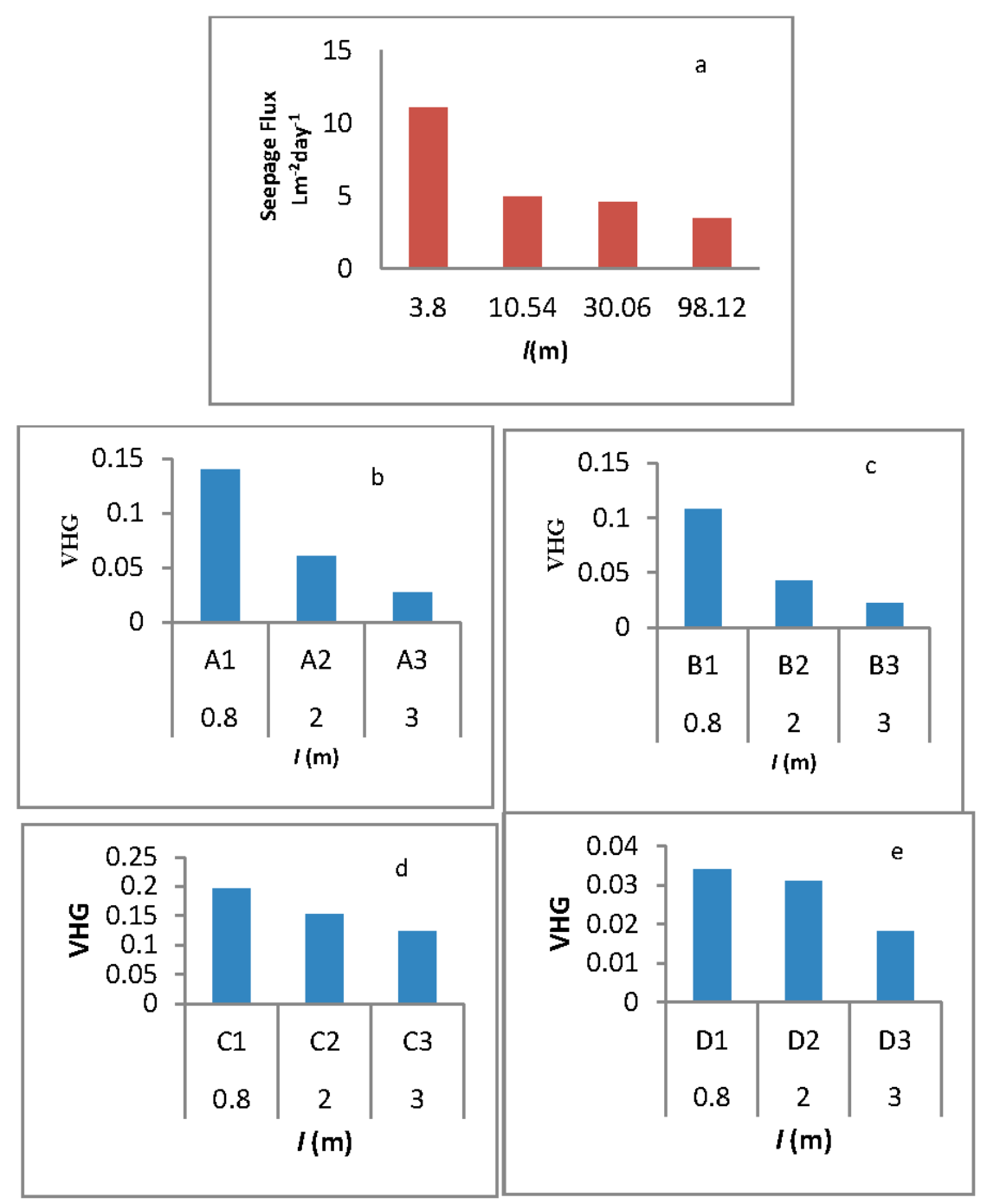

Figure 3: Relationship between groundwater recharge and distance from shoreline at Lake L5, UTP (a) with seepage meter (b)-(e) with mini piezometers $[l=$ distance from shoreline $]$.

of the mini piezometer, the higher the level of groundwater in the pipe $\left(h_{1}\right)$. The results from the study were similar to the ones obtained by Rautio and KorkkaNiem [5] and Rosenberry and LaBaugh [16] in which their hydraulic head differences $(d h)$ did not exceed $30 \mathrm{~cm}$. It also confirmed what was obtained using the seepage meter in relation to shoreline distance and amount of groundwater recharge. 
Table 2: $\quad$ Mini piezometer data collected at Lake L5, UTP.

\begin{tabular}{|c|c|c|c|c|c|c|c|}
\hline Station & Locations & $I(\mathrm{~m})$ & $d l(\mathrm{~cm})$ & $h_{1}(\mathrm{~cm})$ & $h_{2}(\mathrm{~cm})$ & $d h(\mathrm{~cm})$ & VHG \\
\hline \multirow{4}{*}{1} & $\mathrm{~A} 1$ & 0.8 & 50 & 20 & 13 & 7 & 0.140 \\
\cline { 2 - 8 } & $\mathrm{A} 2$ & 2 & 100 & 23 & 17 & 6 & 0.060 \\
\cline { 2 - 8 } & $\mathrm{A} 3$ & 3 & 150 & 65 & 61 & 4 & 0.027 \\
\hline \multirow{3}{*}{2} & $\mathrm{~B} 1$ & 0.8 & 120 & 27 & 14 & 13 & 0.108 \\
\cline { 2 - 8 } & $\mathrm{B} 2$ & 2 & 120 & 35.2 & 30 & 5.2 & 0.043 \\
\cline { 2 - 8 } & $\mathrm{B} 3$ & 3 & 120 & 42.6 & 40 & 3 & 0.022 \\
\hline \multirow{3}{*}{3} & $\mathrm{C} 1$ & 0.8 & 168 & 109 & 76 & 33 & 0.196 \\
\cline { 2 - 8 } & $\mathrm{C} 2$ & 2 & 170 & 110 & 84 & 26 & 0.153 \\
\cline { 2 - 8 } & $\mathrm{C} 3$ & 3 & 189.4 & 114.5 & 91 & 23.5 & 0.124 \\
\hline \multirow{3}{*}{4} & $\mathrm{D} 1$ & 0.8 & 103 & 37.5 & 34 & 3.5 & 0.034 \\
\cline { 2 - 8 } & $\mathrm{D} 2$ & 2 & 146 & 52.5 & 48 & 4.5 & 0.031 \\
\cline { 2 - 8 } & $\mathrm{D} 3$ & 3 & 136 & 53.5 & 51 & 2.5 & 0.018 \\
\hline
\end{tabular}

$I$ = distance from shoreline $(\mathrm{m}), d l=$ the vertical distance between the lakebed and the midpoint of the perforated mini piezometer $(\mathrm{cm}), h_{1}=$ the level of groundwater in the mini piezometer, $h_{2}=$ the lake water level, $d h=$ head difference $(\mathrm{cm})$, VHG $=$ Vertical Hydraulic Gradient.

\section{Conclusions}

The overall objective of this study was to examine the groundwater-lake water interactions. The goal was specifically to investigate the directions and rates of groundwater seepage with mini piezometers and seepage meters. This was actualized from the conducted experiments. The above results indicated that water was being recharged from groundwater to the lake as at the time the experiments were conducted. The average seepage flux of the lake was $6 \mathrm{Lm}^{-2}$ day $^{-1}$ and VHG was 0.080 . However, directions and flow rates between the lake water and groundwater could be dynamic and change over time and space due to response to seasonal weather conditions and water flow. In order to fully ascertain the groundwater - surface water interactions of Lake L5, it is recommended that a longer period of study be conducted under different hydrological conditions and time of the year and at several locations.

\section{Acknowledgements}

The authors are thankful to the management and authorities of the Universiti Teknologi PETRONAS, especially the Department of Civil Engineering for the facilities provided during this study. 


\section{References}

[1] Lim, C. H. State of Water Resource in Malaysia: Dialogue on "Water Environment Partnership in Asia WEPA”, Ministry of Natural Resources and Environment: Malaysia, 2008.

[2] Nurlidia, M., Muhammad, A. Z. M. S. and Hafizah, A. Investigation of Pb Dispersal and Accumulation around Untreated Former Tin Mines in Perak, Malaysia, 2nd Int. Conference on Chemical, Biological and Environmental Engineering (ICBEE2010): Kuala Lumpur, 2010.

[3] Muhammad, A. A., Mohd, J. M. and Ismail, Y. Study of Water Quality and Heavy Metals in Soils and Water of Ex-Mining Area of Bestari Jaya, Peninsular Malaysia, Int. Journal of Basic and Applied Sci. Vol. 10, No. 3, 2010.

[4] Brodie, R. S., Baskaran, S., Ransley, T. and Spring, J. (2009). The seepage Meter: Progressing a simple method of directly measuring water flow between surface water and groundwater systems, Australian Journal of Earth Sciences: An International Geoscience Journal of the Geological Society of Australia, 56: 1, 3-11, 2009.

[5] Rautio, A. and Korkka-Niem, K. Characterization of groundwater - lake water interactions at Pyhajarvi, a lake in SW Finland, Boreal Environment Research 16: 363-380, 2011.

[6] Kalbus, E., Reinstorf, F. and Schirmer, M. Measuring methods for groundwater - surface water interactions: a review. Journal of Hydrol. Earth Syst. Sci., 10, 873-887, 2006.

[7] Hirsch, J. D. and Randazzo, A. F. Hydraulic seepage within an astatic Karstic lake, North - Central Florida. In: Groundwater: Past Achievements and Future Challenges (ed. by O. Sililo), 159-164. A. A. Balkema, Rotterdam, The Netherlands, 2000.

[8] Makoto, T. Change in Groundwater Seepage Rate into Lake Biwa, Japan, Japan Journal Limnol., 56, 4, 261-267, 1995.

[9] Rosenberry, D. O. A seepage Meter designed for use in flowing water, Journal of Hydrology, Vol. 359, pp. 118-130, 2008.

[10] Lee, D. R. A device for Measuring Seepage flux in lakes and estuaries, Limnol, Oceanogr. 22: 140-147, 1977.

[11] William, W. W. and Kevin, E. S. Results of Seepage meter and mini piezometer study, Lake Mead, Nevada, Journal of Groundwater, Vol. 22, No. 5, 1984.

[12] Simpkins, W. W. A multiscale investigation of groundwater flow at clear lake, Iowa. Groundwater Journal, 44: 35-46, 2006.

[13] Boyle, D. R. Design of a seepage meter for measuring groundwater fluxes in the nonlittoral zones of lakes - Evaluation in a boreal forest lake, Limnol, Oceanogr., 39(3), 670-681, 1994.

[14] Belanger, T.V. and Montgomery, M.T. Seepage meter errors. Limnology and Oceanography 37: 1787-1795, 1992. 
[15] Lee, D. R. and Cherry, J. A. A field exercise on groundwater flow using seepage meter and mini - piezometers. Journal of Geol. Education, 27: 620, 1978.

[16] Rosenberry, D. O. and LaBaugh, J. W. (eds.). Field Techniques for estimating water fluxes between surface water and groundwater, techniques and methods 4-D2. SGS, Reston, Virginia, 2008.

[17] McCann, K., Olson, L. and Hardy, P. Lake Adair Diagnostic Study, City of Orlando Public Works Department, Storm Utility Bureau, Florida, USA, 1997. 